\title{
ALTERIDADE E SOCIABILIDADE KAXINAUÁ: \\ Perspectivas de uma antropologia da vida diária*
}

\author{
Cecilia McCallum
}

Introdução

O que é "sociabilidade" para a antropologia social e simbólica? Marilyn Strathern, na sua obra-mestra The gender of the gift, faz uma arqueologia do uso do termo na própria obra de Simmel. Sociabilidade, ela diz, tem a ver com a constituição social e moral de "relatedness" (o estado de estar relacionado). Seguindo Strathern e a sua análise da sociabilidade nas sociedades da Melanésia, eu procuro tanto o lado social quanto o lado moral da sociabilidade, e ainda vejo a produção da sociabilidade na Amazônia como decorrente da "ação humana" (buman agency) em suas formas variadas. Faço uma distinção entre "socialidade" e "sociabilidade" para designar diferenças importantes em formas de construção de relações sociais, que sustentam fundamentalmente o processo social.

Antes de tratar de etnografia específica, é preciso examinar com mais detalhe a discussão antropológica sobre a região. O que significa "sociabilidade" na literatura sobre os povos indígenas da Amazônia? Uma breve excursão nas páginas que tenho à mão me leva a suspeitar que existem vários significados que são, à primeira vista, incompatíveis. Neste artigo, tomo a sociabilidade Kaxinauá como ponto de partida para uma exploração destes significados e busco a compatibilidade entre eles.

A questão é delicada. Não se pode dizer que o problema se resume a diferenças do tipo teórico-inspiracional: antropólogos de certo lugar e escola - por exemplo, o estruturalismo no Brasil — em oposição a outros de origem distinta — por exemplo, o empirismo na Grã-Bretanha. Os que tentam buscar nestas fontes teóricas de inspiração uma explicação para os usos diferenciados do termo "sociabilidade" recorrem, de fato, a um sistema onomástico bastante primitivo, mas por enquanto bem difundido entre os americanistas. Mesmo aqueles que nem olham para os lados - que esquecem de mencionar os trabalhos dos colegas/rivais - o utilizam, ao menos implicitamente. Colocando rótulos nos seus colegas, podem então virarlhes as costas, se assim o quiserem. Tal rotulação sustenta uma prática desnecessária entre os antropólogos, de não 
aprofundar muito a leitura — e o entendimento — das trajetórias analíticas dos textos dos seus "outros". Digo isso num sentido específico. Não é que não haja trocas constantes, apreciações valiosas e toda uma tradição de respeito aos outros. A tendência mais atual no americanismo tropical, podemos dizer, é definida por uma imbricação forte, de tal modo que, apesar de todas as diferenças, não falta comunicação ou consenso sobre o que é de valor e de interesse. Assim, quem utiliza "sociabilidade" (e suas variantes) o faz porque o termo apreende algo de significativo no momento, no esforço de aprofundar nosso entendimento sobre os processos sociais dos povos em questão. É exatamente a falta de discussão sobre os vários significados do termo, que revela a ausência de um entrosamento maior entre analistas, o que eu lamento.

Afirmo que o assunto é delicado por mais um motivo. Está ficando cada vez mais claro que as fortes diferenças entre os ethos, as moralidades, as práticas e os estilos sociais, não só entre grupos mas também entre representantes de cada grupo, deveriam ser levadas mais em conta. Joanna Overing mostra que o pacifismo reina nos discursos moralizantes e nas práticas sociais internas dos Piaroa. Ela constrói uma teoria mais global da dinâmica social entre os povos das terras baixas em decorrência disso e de práticas semelhantes em outras regiões. Carlos Fausto, por outro lado, debruçou-se sobre uma grande falta de pacifismo entre os Parakanã, que fizeram da guerra um jeito de ser e uma raison d'être. Com bastante êxito, ele constrói uma teoria da guerra e da sociabilidade nas terras baixas que ignora as conclusões de Overing sobre o papel do ethos da vida diária, apesar de respeitar sua análise sobre violência e canibalismo simbólico na construção da alteridade. A diferença entre os dois autores, deve-se notar, não é só teórica.

Tampouco é só uma questão de ênfase, com Overing focalizando a vida diária e Fausto, a vida cosmológica ou imaginativa. Temos de aceitar que a diferença se deve também às fortes diferenças de valores, estilos de vida e ethos entre os dois povos. Tratando da sociabilidade como um aspecto da guerra, Fausto está sendo fiel aos seus instrutores Parakanã, a maioria dos quais são guerreiros aposentados. Assim como Overing reflete a ênfase dos Piaroa. Como, então, aproximar mais as trajetórias analíticas dos antropólogos dos diversos povos?

O primeiro passo é voltar ao começo, meu começo com os Kaxinauá, um povo de língua Pano, uma população de cerca de 5 mil pessoas, que atualmente vive no alto rio Purus e nas cabeceiras do Juruá, no Estado do Acre, e também nas cabeceiras do Purus, no Peru. Retomo a sociabilidade como esta é construída no curso da vida diária, focalizando a questão da alteridade. Assim, preparo o terreno para uma discussão mais ampla sobre a "sociabilidade" entre os povos das terras baixas.

\section{"Socialidade": o sentimento como ordem social}

É verão. O rio está baixo, as praias se estendem e a água turva do rio Purus corre gentilmente. As mulheres conseguem remar rio acima sem muito esforço. Rindo, param numa praia para comer as melancias de Ana, que convida a tia, a irmã e a prima/cunhada a colher uma e a devorá-la. As crianças, com jeito, conseguem pedaços generosos e todas voltam à canoa. Deixam a colheita dos amendoins para a volta, pois têm de ir de mãos vazias.

As mulheres vão em visita. Vão bai kai, comer a comida dos amigos e dos parentes distantes que moram em outra aldeia. Vão em busca de presentes, especialmente alimentos crus, para trazerem de volta à casa. Assim, vão obrigar as mulheres da outra aldeia a criar ou recriar laços sociais com as suas "outras" Kaxinauá. Ao mesmo tempo, vão "predar" os frutos das atividades produtivas das anfitriãs, apoiadas na ética da reciprocidade e da troca de visitas entre as mulheres. Saindo da aldeia, para o seu exterior, as mulheres adotam uma postura masculina ao se relacionarem com os habitantes deste exterior na base da troca. A aparência, porém, é de parentes, e a linguagem e estilo da visita é todo parentesco, como veremos. 
Para os Kaxinauá, os homens adquirem, durante sua vida, os saberes e as forças — que designo agency (McCallum, 1989 e 1996) - para lidar com o exterior. A relação que devem desenvolver com os vários espaços e tempos do exterior é de produção. Eles têm de buscar saberes, objetos, presas, comidas, remédios e produtos variados, que trazem de volta para casa e inserem nos canais que os farão parte do processo de reprodução social. Existem duas modalidades de relacionamento com os que habitam o exterior: a predação e a troca, ambas especialidades masculinas.

A contrapartida do agency masculino é o feminino. Cabe às mulheres adultas, já impregnadas de saber e força criadora — adquiridos mediante um longo processo de fabricação corporal (McCallum, 1989 e 1996) —, processar as aquisições e produtos masculinos e torná-los apropriados ao consumo. Uma vez transformados, os produtos consumíveis serão servidos pelas mulheres aos consumidores, num gesto (ou série de gestos) que designa o poder feminino de dar, ou melhor, de presentear aos que vão consumir. Eis a relação que é a especialidade feminina, opima- "fazer consumir". Assim as mulheres Kaxinauá, como outras mulheres de outros grupos amazônicos, iniciam e reiniciam a construção do parentesco, com o dom prosaico e cotidiano do alimento preparado (McCallum, 1989; Gow, 1989 e 1991; Belaúnde, 1992). Elas têm, portanto, uma relação especial com o interior, em um duplo sentido. Quando o homem volta da floresta ou da cidade, ele se dirige à posição da mulher, que ocupa, naquele momento, o eixo central do interior em relação ao seu homem. Colocar nas mãos da mulher o produto da caça ou dos negócios é afirmar a centralidade da mulher e efetuar a reinserção do homem no interior. Além disso, a mulher, ao transformar e distribuir o produto, não só simboliza o interior mas também o recria, pois fazer parentesco é fazer o lugar dos "meus parentes". Este espaço é o lugar da humanidade como um fenômeno vivido diariamente. Este fenômeno é nada mais que o produto dos trabalhos e movimentos incessantes dos seres humanos verdadeiros ("a gente") que se pensam como parentes e que se tornam sempre mais (ou menos) parentes através destas atividades.
Porém, não devemos confundir a mulher Kaxinauá com o interior e o homem com o exterior. O que se tem aqui é uma série de relações simbólicas e práticas que os Kaxinauá vivenciam entre si no fluxo do processo constitutivo da socialidade. Há que ter relação com o exterior, e há que ter relação com o interior, relações realizadas fisicamente por homens e mulheres, e estas relações devem se relacionar para produzir o socius. A força por trás desta seqüência está nas pessoas, nas suas capacidades específicas, o male agency de um lado e o female agency do outro. As relações de produção "masculinas" que chamamos de predação ou de troca estão relacionadas, em um segundo momento, à relação de produção feminina, que é o momento-chave no processo de fazer socialidade — o "fazer consumir".

Penso isso da seguinte forma: a agência humana (buman agency) é única, no sentido de que é direcionada ao mesmo fim: produzir socialidade. Socialidade é um estado momentâneo na vida social de um grupo, definido pelo sentimento de bem-estar e pelo auto-reconhecimento como um grupo de parentes em plena forma. Designo isso, junto com Overing (1989 e 1991) e seguindo Goldman (1963), "high community morale". Esta noção designa um estado moral de uma comunidade, mas não deve ser entendida como um conceito que substitui "organização social" ou outra ferramenta de cunho sociológico. Qualquer análise de organização social Kaxinauá precisa levar em conta a criação da socialidade, exatamente porque o conceito captura a visão própria dos índios sobre o sentido das suas vidas e a dinâmica das suas atuações no mundo. Neste sentido, todos eles deveriam estar empenhados na mesma direção, com o mesmo fim. Por isso a noção é mesmo o eixo da filosofia moral dos Kaxinauá, pois ninguém consegue, na prática, atuar apenas fazendo a socialidade. Ao contrário, é importante ressaltar que qualquer pessoa também pode atuar de forma a desfazê-la. O impulso de "anti-socialidade" faz parte do cotidiano, tanto quanto o seu contrário. A organização social, com todos os seus processos e padrões, engloba tanto socialidade como anti-socialidade.

Nos autores citados acima, a análise da vida social, da cosmologia e da alteridade gira em torno destas 
observações sobre a centralidade da socialidade para os próprios índios. Nossos leitores têm reagido com uma certa benevolência, embora com ceticismo, em relação ao excesso de utopia presente nesta visão. Por exemplo, Taylor (1996, pp. 206-207) escreve que os britânicos são bons quando lidam com o amor, mas que os estruturalistas franceses e brasileiros são melhores quando têm a ver com o ódio:

Sociality as inherently affective memory has been described with great finesse and insight by what we, in Paris, call the English school of Americanism. Nevertheless, our colleagues' accounts have often struck me as somewhat one-sided and indeed surprisingly angelic, for they tend to minimize a vital component of social relations, namely hostility or vindictiveness [...] Hostility is a particularly important aspect of social relations and of the psychological configurations that go with them [...]

E Taylor continua afirmando que isso é especialmente importante no caso dos povos Jivaros, entre os quais aprender a odiar é tão importante quanto aprender a amar. De novo, confrontamos as diferenças palpáveis entre os povos, e não só entre os antropólogos. Mas quero ressaltar que também acho que o ódio é fundamental nas relações sociais para os Kaxinauá (e os povos das terras baixas em geral). Só que, para os Kaxinauá, o processo de expulsar o ódio do interior do socius é constante; eles sempre tentam restringir sua expressão em relação aos outros. Porém, o fato é que o ódio é um componente onipresente na posição que o sujeito de dentro assume em relação ao outro. O ódio promove a alteridade, onde quer que seja acionado.

Já para Viveiros de Castro (1996b), a escola britânica (que, devo constatar, é composta também por um uruguaio, uma peruana, uma norte-americana, um escocês, entre outros) é um estilo que ele denomina "a economia moral da intimidade". Diz o autor:

This style tends to privilege the local group's internal relationships - defined by sharing and caring between relatives - at the expense of interlocal relationships, conceived by native ideologies as defined by a reciprocity always on the verge of the predatory violence that also characterizes the relations between society and nature. It theoretically values production over exchange, practices of mutuality over reciprocity structures, and the morals of consanguinity over the symbolics of affinity. Although it rejects the notion of "society" as a totality [...] this model, with its essentially moral view of "sociality", nevertheless presents curious analogies with the Fortesian concept of kinship as "Amity". In addition, in a certain way its critique of the public/domestic opposition leads to the reduction of society to the domestic level. (Viveiros de Castro, 1996b, p. 189)

Por enquanto, não comento esta interpretação, além de dizer que acho que ela representa razoavelmente bem a opinião de um bom contingente de leitores formados no estilo desenvolvido pelo próprio Castro, que ele designa "a economia simbólica da alteridade". Veremos se as oposições que faz - troca em oposição a produção, compartilhar e cuidar (práticas da mutualidade) em oposição às estruturas da reciprocidade, relações intralocais em oposição às relações interlocais etc. — caem bem com a análise da dinâmica entre socialidade e anti-socialidade Kaxinauá.

Socialidade depende do poder produtivo e reprodutivo dos adultos. A pessoa precisa conhecer, exercer atividades produtivas e ter relações sexuais (vistas como um tipo de produção) para poder fabricar crianças. Para os Kaxinauá, como muitos outros povos amazônicos, a base da socialidade se resume no valor, aliado a esses poderes, da generosidade. Uma boa pessoa - que age como um parente adulto - é duapa, bondosa, carinhosa e simpática. Uma pessoa maldosa é yauxi, sovina, e sinata, raivosa. Age como um inimigo ou um estranho qualquer, recusando-se a compartilhar seus bens e alimentos. No seio de qualquer assentamento ou aldeia Kaxinauá estes comportamentos co-existem, fazem parte do cotidiano. Assim, a alteridade não é uma propriedade só dos seres que habitam o exterior, mas também dos humanos comuns. A atividade de constituir socialidade, então, é uma constante luta contra o deslizamento para o seu oposto, quando os próximos se mostram outros através do comportamento sovina e 
agressivo. Uma atividade importante das lideranças, por exemplo, é sempre falar de uma maneira homelítica nas reuniões. As suas palavras têm um efeito material nos corpos dos ouvintes, moldando-os, supostamente enchendo-os de valores, capacidades e desejos constitutivos de socialidade (McCallum, 1990). Um outro exemplo pode ser tirado do processo de fabricação da pessoa. Os adultos procuram plantas e outras substâncias medicinais para produzir capacidades sociais adequadas nos filhos e netos - a capacidade de ouvir/entender (ninka-), de ver (uin-), de ser calmo, de falar, de caçar etc. (McCallum, 1996 e 1998).

Tudo, claro, depende do ponto de orientação, da perspectiva. Só se deve ser generoso com parentes, e não com estranhos. Quando uma pessoa age de maneira raivosa ou sovina, ela cria uma relação mais distante entre si própria (o ator) e o receptor. $\mathrm{O}$ ator rejeita, o receptor recua. A ação amplia a distância entre os dois, criando, assim, alteridade do ponto de vista de ambos. Do ator, a visão do outro como não-parente precede a visão do receptor complementar, que passa a entender o ator não mais como parente em potencial, mas como não-parente (pelo menos naquele momento). Uma perspectiva segue a outra. Tudo se orienta em relação aos corpos das pessoas, vistos sempre como agentes/atores que agem sobre outros agentes, e não como organismos estáveis ou acabados, sítios de pontos de vistas fixos. $\mathrm{Na}$ vida diária, nos processos que fazem e desfazem osocius, o perspectivismo é relativo. 1 A mulher não é o interior (que, como espaço, depende do ponto de vista do sujeito); simplesmente ela o representa em um momento e o faz em outro. Portanto, as relações com entes ou produtos externos também não são prerrogativas dos homens, como as relações com entes ou produtos internos não são prerrogativas das mulheres. A afinidade pode ser feminina e as mulheres podem ir em visita. Voltemos à expedição das mulheres subindo o rio Purus.

Chegando ao entroncamento na metade do caminho fluvial, elas desembarcam, atam a canoa e sobem o barranco. Entram na floresta pela trilha que vai diretamente para a outra aldeia. Andam rapidamente até chegar a um igarapé, onde tomam um banho para lavar seus corpos suados. Algumas usam vestidos novos e limpos, costurados por elas mesmas nas máquinas compradas por seus maridos ou pelotuxanana cidade. Penteiam os cabelos compridos, passando um óleo cheiroso que conseguiram no marreteiro ou na cooperativa da aldeia. Estão prontas.

Chegando à primeira casa, percebem que há apenas uma menina. A menina, que está tomando conta do irmão pequeno, saúda uma pessoa de cada vez:

Min ma juai, Evan?(Você já está chegando, Tia-mãe?)

Min ma juai, Yayan? Tsaben?(Você já está chegando, Tiasogra? Prima-cunhada?)

As mulheres respondem, sem subir a escadinha que leva à sala aberta da casa (que é no estilo regional, de paxiúba e palafitas, porém bem maior e mais aberta do que as casas dos neobrasileiros). Seguem o caminho que leva à casa de outra amiga, cunhada de Ana. Algumas mulheres sobem, outras seguem em frente, para visitar outra casa. Ana, as mulheres e suas crianças sentam no piso de paxiúba, num canto da sala. A mais velha ou mais importante é convidada a deitar na rede social. Respondem à saudação dirigida a cada uma delas: "En juaii. (Eu estou chegando)". Então a anfitriã pergunta: "Min java piai?(O que você come? Já comeu?])".

A pergunta é bastante retórica. Todas sabem que a anfitriã vai servir comida. O que não se sabe é o tipo da comida. A partir dela será possível deduzir várias coisas, como o sucesso produtivo do casal e a estima que a anfitriã tem para com a convidada (que, por sinal, provavelmente não foi convidada e sim está fazendo uma visita surpresa). As mulheres aguardam sentadas enquanto a anfitriã busca um prato de aipim cozido (talvez em molho de amendoim, ou com o molho denawanti, uma folha verde). Agindo formalmente, ela coloca o prato na frente das visitas, ao alcance de todas. Elas, porém, continuam aguardando. $\mathrm{O}$ momento crítico chega. O que acompanha o aipim? Com sorte, tem caiçuma, um tipo de bebida feita seguindo várias receitas, geralmente de milho. Primeiro, as mulheres esperam alguma carne ou peixe, para poder comer junto 
(nai-) com o aipim. Muitas vezes a anfitriã pede desculpas. Não tem nada: têm de aguentar só com aipim. Ela traz um pouco de sal, ou talvez manteiga de amendoim ou amendoim torrado na casca para as mulheres poderem comer. Elas atacam, comendo com eficiência, parando só para conversar, quando ouvem as novidades sobre os parentes e afins na aldeia. A caiçuma é servida em um vasilhame fundo, com uma concha de alumínio que cada uma enche e leva à boca.

Se a anfitriã tiver alguma carne ou peixe escondido na cozinha, este só será servido se ela quiser bem às visitas. Ela pode simplesmente pedir desculpas pela falta de comida decente, querendo guardá-la para si mesma, e assim afastarse socialmente delas. Se houver muita caça ou peixe em casa, ela não os esconderá. Uma visita bem recebida vai ainda levar uma porção consigo. Porém, a distribuição, seja para consumo imediato, seja para consumo posterior, nunca é igualitária entre as visitas. Se a hospitalidade mínima mais completa é observada, um único prato é dividido entre todas as mulheres. Quando se quer destacar uma pessoa, e assim criar um laço mais forte com ela, a anfitriã seleciona um pedaço melhor - mais gorduroso, carnudo - e o coloca diretamente nas mãos da visita especial. Cabe às próprias visitas dar de comer aos filhos. Elas tiram um peixe ou pedaço de carne do prato comum, se não tiver uma porção particular, juntam aipim, e dão para os filhos. Só os maiores compartilham a comida.

Esta refeição imita as refeições comuns dentro das aldeias em vários sentidos. Sempre existe uma certa formalidade na hora de servir. Os atos de pegar aipim na panela, arranjar no prato e servir são sempre elegantes, algumas mulheres se destacando nos seus movimentos e gestos. Certas mulheres são conhecidas como boas cozinheiras, fazendo cada prato no ponto, nem queimado nem cru, nem grosso nem aguado demais. Essas provavelmente são também trabalhadoras caprichosas, e nas suas casas não faltam os ingredientes básicos da culinária Kaxinauá. São ainbu kuin, "mulheres verdadeiras". Mostram-se como tais ao poder servir bem aos convidados e convidadas.
Detenho-me nestes detalhes porque, do ponto de vista Kaxinauá, eles são importantes. Talvez, à primeira vista, o ato de preparar e servir comida assemelhe-se a um simples "compartilhar", uma "reciprocidade generalizada", e tenha o sabor de meros atos domésticos, sem uma maior importância sociológica. Preparar e servir comida (ou se negar a fazê-lo) é uma linguagem sofisticada para falar do social e, ao mesmo tempo, para efetuar mudanças materiais sensíveis nos agentes do social. O alimento, uma vez ingerido, modifica e fortalece o corpo, e quem o consome vai sempre lembrar de como foi "feita comer".

Quando estão "satisfeitas", as mulheres se levantam. A anfitriã procura dar a cada uma delas alguma coisa para levar para casa, geralmente um alimento cru como banana ou aipim. Assim, ela não só alimenta as visitas, fazendo-as mais parentes, como fornece o material para que elas mesmas alimentem outros parentes. Neste sentido, visitar pode ser entendido como uma atividade "predatória". Um motivo para participar de uma expedição é conseguir alimentos ou até outras coisas. As visitas podem também pedir alguma coisa que está à vista: "E a inanve! (Me dá!)". A anfitriã não ousaria recusar. Seria o cúmulo dos maus modos, uma afirmação aberta de hostilidade. No final do dia, as cestas estarão cheias. Saindo da primeira casa, as mulheres se despedem. Tudo se repete nas outras casas que oferecerem a possibilidade de uma boa recepção. As mulheres podem comer até seis ou sete refeições, uma depois da outra. Em algumas casas, só acham aipim. Em outras, um cafezinho no estilo regional, ou um prato de farinha seca. Mas elas sempre são informadas sobre quem tem que tipo de caça, e assim podem se programar para poder passar bem. Quando sabem que a anfitriã tem e não recebem, podem comentar em voz baixa ao saírem, mal alimentadas, de uma casa: "Chanichakyamaki. Javen nami yauxixuki, nuku pima makidan!(Ela mentiu pra caramba. Ela sovinou a carne e não nos fez comer!)".

Assim, sabem que a anfitriã não é uma amiga íntima, nem as considera como parentes próximos. Porém, ao mesmo tempo, todas reconhecem que cada mulher é capaz de fazer o mesmo com visitas surpresas. Há uma troca de atos constitutivos da anti-socialidade, assim como há uma troca 
de atos constitutivos da socialidade. Nenhuma mulher é perfeita, generosa — uma "mulher verdadeira" — todo o tempo. Por isso, a discussão da produção do sociusnão deve levar o leitor a um entendimento "irênico" ou "angelical" dos ameríndios. Não se deve confundir a ausência de apetite guerreiro por parte de um certo povo com excesso de utopianismo por parte do antropólogo que o estuda.

Com estas visitas, as mulheres conseguem refazer e iniciar laços sociais com pessoas morando em lugares distantes. Visitas masculinas também são convidadas a comer da mesma forma, mas não levam presentes de alimentos crus. A mesma lógica e ritual são seguidos em visitas mais demoradas aos parentes que moram longe, no Peru ou ao longo de outros rios como o Énvira ou Jordão. É preciso comer para afirmar, refazer ou criar a relação. Como discuto em McCallum (1997), os estrangeiros bons também são "criados" e "fabricados" com comida durante o processo de torná-los mais "the same" ("os mesmos") e menos "outros".2 Porém, já que, em muitos casos, não podem devolver o gesto, raramente viram parentes próximos de um Kaxinauá. O fazer comer entre pessoas da mesma geração deve ser mútuo.

Assim, tenho que discordar de Fausto quando este afirma que "na maioria das sociedades ameríndias, o xamanismo e a guerra são formas de interação com subjetidades outras, sejam elas humanas ou não. Por meio dessas atividades, as unidades políticas amazônicas, sociologicamente fechadas, abrem-se para o exterior." (Fausto,1997). Este conjunto de idéias não dá conta das práticas Kaxinauá sem classificá-los como uma minoria sem importância, ou uma aberração cultural.

As mulheres fazem este tipo de visita mais freqüentemente durante o verão. Os homens às vezes as acompanham, mas pouco. É mais comum que uma família inteira se desloque durante alguns meses da estação seca, às vezes procurando saber se devem mudar de aldeia e/ou país. O primeiro passo pode ser uma visita demorada aos parentes. Nestes casos, depois dos primeiros dias, a família recém-chegada começa a produzir como qualquer outra, os homens caçando e pescando, as mulheres buscando comida no roçado de uma parenta, durante expedições coletivas femininas aos roçados (McCallum, 1989), ou nas visitas a outras casas para poder cozinhar, alimentar a família e distribuir comida às outras pessoas.

Para concluir esta discussão dos processos de fabricação de socialidade, volto à questão da alteridade. Como nas demais culturas indígenas, os Kaxinauá concebem o outro segundo dicotomias radicais que tanto possibilitam a transformação dos seres em uma coisa oposta, quanto dependem, para a criação do mesmo (same), da aquisição de qualidades, saberes e poderes dos outros. Assim, os vivos podem ser transformados em mortos — até os Deuses —, os xamãs tornam-se bichos, os espíritos visitam as aldeias, comem, bebem, dançam, tentam casar-se com os vivos. Aqui não discuti nenhum exemplo destes processos ou acontecimentos mais exóticos entre os Kaxinauá (perfeitamente possível, já que eles também possuem um repertório amplo). Preferi explorar a criação e destruição da alteridade mais perto de casa, entre os vivos, os parentes e/ou afins. Concentro-me na alteridade "doméstica" porque esta raramente é considerada como fazendo parte do mesmo nível da economia simbólica constitutiva da sociedade ou das relações entre grupos sociais. Mesmo assim, os Kaxinauá fazem dos pequenos rituais aqui descritos um meio poderoso de constituir sociabilidade externa, e não só interna, entre não parentes e não só parentes, e entre etnias também, como espero ter mostrado. $\underline{3}$ Resta, então, discutir esta noção de sociabilidade externa e os demais tipos de relação que a constituem - a troca e a predação.

\section{Sociabilidade: de troca, guerra, indiferença e} ódio

A descrição de socialidade que elaborei aqui difere notavelmente do uso da noção de sociabilidade ousociality por outros autores, como por exemplo Turner (1995), Descola (1994) e Fausto (1997). O contraste pode ser mapeado, nos termos de Taylor ou Viveiros de Castro, 
como o efeito da ênfase deste modelo na moralidade do íntimo como geradora do social. A "sociabilidade" se refere, então, a outra esfera, onde reinam o ódio ou a indiferença: o externo. É possível tentar fazer um contraste apelando para a inserção destes usos do termo "sociabilidade" na "economia simbólica da alteridade" ou, no caso de Turner, na "economia política de controle" (Viveiros de Castro, 1996b).

Turner (1995) faz referência à sociality no título do seu artigo, mas não trata diretamente do termo. Ele mostra como, para os Kayapó, modificações feitas diretamente nos seus corpos podem ser vistas como um meio potente de regulamentar relações sociais, além da identidade social da pessoa definida pelas relações (idem, p. 147). Neste tipo de sociedade, a troca não é primariamente de bens, e sim de símbolos de aspectos valorizados da identidade social, como marcas de status, ou performancede papéis e os valores a eles associados. Ele dá como exemplos performances verbais ou visuais. Quem assiste e aceita uma performance está recebendo valores, como um recipiente de kulaaceita conchas ou outro dom. Assim, se entendo Turner, a sociabilidade é constituída por meio da troca de valores sociais ligados materialmente ao corpo. Esta troca assume a forma de uma produção pessoal para o consumo auditivo e visual dos outros (a coletividade). A coletividade consome os valores gerados na superfície do corpo ou através dos seus poderes, num ato análogo ao recebimento de um objeto de valor nas sociedades onde a circulação de bens é a base da sociality. A circulação de valores é feita como comunicação e este é o processo de constituir a sociabilidade.

Assim, a teoria de Turner recorre a um modelo clássico de análise social, porém bem adaptado à etnografia Kayapó e à ênfase, entre os povos indígenas das terras baixas, na corporalidade como sítio da construção dosocius (Seegeret al., 1987; Viveiros de Castro, 1996b; Gow, 1991, entre muitos outros). Ele faz questão de ressaltar a continuidade entre o "corpo social" oferecido para consumo ritual, visual ou auditivo e o corpo do dia-a-dia, inserido como é na práxis social. Para os Kayapó, o corpo não é uma totalidade única, e sim feito de subsistemas e/ou aspectos da corporalidade (como sexualidade, saúde, ou os valores, nomes, riquezas (nekrets) e representações corporais comunicados naperformance). Porém, Turner assinala que estas comunicações (que, pelo que entendo, formam a base da sociabilidade porque projetam valores e significados que transcendem o dia-a-dia) são feitas por meio da apropriação social do corpo material. O corpo material é, para os Kayapó, uma realidade material do corpo-em-ação. Turner (1995, p. 166) escreve: "Appropriation' in this sense is tantamount to the social production of both social body and embodied subject, including the cultural meanings and significations in terms of which they are socially defined".

Turner nota que a subjetividade incorporada às pessoas como agentsé construída de muitos modos de subjetividade. Esses modos são heterogêneos e mudam segundo o contexto ou época. Mas o sujeito vê os outros Kayapós como "objetos" que são postos em circulação como valores na roda da sociabilidade.

Turner, neste artigo, não faz da sua noção de sociabilidade uma teoria de relações interétnicas. Ele não explora a relação entre o interior e o exterior, do modo como fazem os "estruturalistas" e aficionados do modelo da "economia simbólica da alteridade". Descola (1994) desenvolve uma análise sofisticada das relações sociais entre os Achuar e os demais habitantes do cosmos e do mundo natural. Para ele, sociabilidade (sociabilité) define não só as relações entre o interior e o exterior, mas também dentro do interior. Oethosda unidade doméstica deve ser caracterizado pelo desejo por uma "vida boa", paz e harmonia no microcosmo da casa (que nem sempre é o caso). Para conseguir este estado, homens e mulheres se especializam em duas sociabilidades complementares: a feminina é de um tipo dirigido para consangüíneos, a masculina é dirigida para os afins. Assim, a agricultura se apóia nas relações sociais de cunho materno que as mulheres desenvolvem com as plantas-espíritos, ao passo que a caça trata das relações sociais afinizadas com outros seres não humanos. Para Descola, sociabilidade é simplesmente o efeito da prática das relações sociais. Assim, ele vê um "continuum de sociabilidade" entre natureza e cultura, dentro de e entre as unidades domésticas. Porém, ele sinaliza uma 
descontinuidade real entre as mulheres e os homens, vendo no controle feminino da horticultura a única esfera de poder feminino autônomo. Os homens dominam a sociabilidade entre grupos locais, controlando a troca de esposas e a guerra.

Para Fausto (1997), há ainda vários tipos de sociabilidade, dependendo do tipo de relação social construída. Estas sociabilidades são hierarquizadas, pois os tipos de relações características de determinados momentos ou processos históricos são governados por um movimento maior. Todos se subordinam ao movimento principal governado pela "predação familiarizante", que está direcionada sempre à produção de novos sujeitos no interior dosocius. Assim, a análise de Fausto lembra a ênfase que Viveiros de Castro (1993) dá ao englobamento das relações locais pelas globais. Fausto mostra como a predação assume a forma de xamanismo ou de guerra, que no caso dos Parakanã se unem. Poderes xamânicos sustentam a guerra. Assim, se sociabilidade é relação social para Fausto, e a relação social suprema é a predação, temos um uso do termo sociabilidade diretamente oposto à socialidade como a defini para os Kaxinauá, ou como Descola define a vida boa dos Achuar. Também se pode observar, neste modo comparativo, que enquanto Turner faz da pessoa o modo de trocar bens, Fausto faz da pessoa o modo de controlar a subjetividade para a produção de novas pessoas. Deve existir um ponto de ligação maior com a socialidade, dada esta ênfase na produção do interior, porém Fausto não considera este lado, com o seu entusiasmo pela guerra e pela predação. O último capítulo da história, me parece, falta no seu modelo: afinal, o que é este sujeito de dentro?

Finalmente, o espaço é pouco para tratar da sociabilidade vista como "troca" e "reciprocidade" (Viveiros de Castro, 1992 e 1993). Fausto prefere colocar a troca em segundo plano, desmentindo o esquema de Viveiros de Castro. Para este último, o modelo básico da relação social é aquele que une o interior com o exterior, no processo de fazer a Pessoa Araweté - vista não como um simples ser vivo, mas como o objetivo da passagem dos seres humanos pela vida. A sociabilidade-enquanto-troca coloca "socialidade" no lugar de algo a ser superado. Não é o suficiente para a criação de uma sociedade realmente social. Assim, a idéia da "afinidade potencial" com sua figura do "terceiro incluído" busca sair do local para efetuar a conexão com o global.

A perspectiva da socialidade também busca a forma (e as formas) de conexão. Porém, seguindo a trajetória delineada pelos Kaxinauá, procuro ver como se busca no global aquilo que vai ser transformado no local, no processo de fabricar uma sociabilidade que extrapole os limites de uma série de relações sociais. "Socialidade" é o produto de muitas sociabilidades, não se resumindo a apenas uma delas. Quando as mulheres vão em visita, estes vários tipos de sociabilidade se entrelaçam. O produto final pode, ou não, ser socialidade.

\section{NOTAS}

1 Refiro-me à discussão do "perspectivismo" na análise da cosmologia e sociologia ameríndia (Lima, 1996; Vilaça, 1992 e 1997; Viveiros de Castro, 1996a).

2 Claro que precisa de muito mais, o que não tenho espaço para discutir aqui. Fazer sexo, falar Kaxinauá, aparecer e trabalhar no estilo de "gente verdadeiro", portar um nome e se relacionar segundo os sistema de metades — são todos aspectos importantes da organização social e fazem parte da constituição da sociality.

$\underline{3}$ Overing (1996) escreve dos Piaroa: "Because their major concerns relate directly to the artful skills of daily life, the Piaroa endow activities that we might see as merely humdrum (preparing a meal, weeding a garden, making a basket, tending a baby) with a significance far beyond any that we might consider". A autora defende o argumento de que a socialidade ideal é atingida por uma comunidade de semelhantes. A hipótese de Overing é a de que a autonomia individual como base dos processos políticos do grupo deve se basear na semelhança entre as pessoas. 


\section{BIBLIOGRAFIA}

BELAÚNDE, Elvira. (1992),Gender, commensality and community among the Airo-Pai of West Amazonia (Secoya, Western-Tukanoan Speaking). Tese de doutorado, London University.

DESCOLA, Philippe. (1994), In the society of nature: a native ecology in Amazonia. Cambridge, Cambridge University Press.

FAUSTO, Carlos. (1997), A dialética da predação $e$ familiarização entre os Parakanã da Amazônia Oriental: por uma teoria da guerra ameríndia. Tese de doutorado, Rio de Janeiro, PPGAS/Museu Nacional/UFRJ.

GOLDMAN, Irving. (1963), The Cubeo: indians of the Northwest Amazon. Urbana, The University of Illinois Press.

GOW, Peter. (1989), "The perverse child: desire in a native Amazonian subsistence economy". Man, N.S., 24: 299314.

(1991), Of mixed blood: kinship and history in Peruvian Amazonia. Oxford, Clarendon.

LIMA, Tânia. (1996), "O dois e seu múltiplo: reflexões sobre o perspectivismo em uma cosmologia Tupi".Mana, 2/2: 21-47.

McCALLUM, Cecilia. (1989), Gender, personhood and social organization among the Cashinabua of Western Amazonia. Tese de doutorado, London School of Economics.

(1990), "Language, kinship and politics in Amazonia".Man, N.S., 25: 412-433.

(1996), "The body that knows: from Cashinahua epistemology to a medical anthropology of lowland South America".Medical Anthropology Quarterly, 10(3): 347-372.
(1997), "Comendo como Txai, comendo com txai: a sexualização das relações inter-étnicas na Amazônia".Revista de Antropologia, 40/1:109-147.

(1998), "O corpo que sabe: da epistemologia Kaxinauá a uma antropologia médica da América do Sul", in Paulo César Alves e Miriam Rabelo (orgs.),Antropologia da saúde: perspectivas e interface, Rio de Janeiro, Fiocruz.

OVERING, Joanna. (1989), "The aesthetics of production: the sense of community among the Cubeo and Piaroa".Dialectical Anthropology, 14: 159-175.

. (1991), "A estética da produção: o senso de comunidade entre os Cubeo e os Piaroa". Revista de Antropologia, 34: 7-33.

. (1996), Under the sky of the domesticated: in praise of the everyday. Manusc.

SEEGER, Anthony, DA MATTA, Roberto e VIVEIROS DE CASTRO, Eduardo. (1987[1979]), "A construção da pessoa nas sociedades indígenas brasileiras",inJ. Pacheco de Oliveira Filho (ed.),Sociedades indígenas e indigenismo no Brasil, Rio de Janeiro, Ed da UFRJ/Marco Zero.

TAYLOR, Anne-Christine. (1996), "The soul's body and its states: an Amazonian persepective on the nature of being human".Journal of the Royal Anthropological Institute Incorporating Man, 2/2: 201:215.

TURNER, Terence. (1995), "Social body and embodied subject: Bodiliness, subjectivity, and sociality and the Kayapó".Cultural Anthropology, 10/2: 143-170.

VILAÇA, Aparecida. (1992),Comendo como gente: formas do canibalismo Wari. Rio de Janeiro, Ed. da UFRJ/Anpocs.

(1997), Canibalismo e morte entre os Warí: reflexões à luz do perspectivismo. Comunicação apresentada ao XXI Encontro Anual da Anpocs, Caxambú, 21-25 de outubro. 
VIVEIROS DE CASTRO, Eduardo. (1986),Araweté: os deuses canibais. Rio de Janeiro, Jorge Zahar Editores/Anpocs.

. (1992),From the enemy's point-of-view. Chicago, Chicago University Press. (1993), "Alguns aspectos da afinidade no Dravidianato Amazônico",inE. Viveiros de Castro e M. Carneiro da Cunha (eds.),Amazônia: etnologia e bistória indígena, São Paulo, NHII-USP/FAPESP.

(1996a), "Os pronomes cosmológicos e o perspectivismo Amérindio".Mana, 2/2: 115-144.

. (1996b), "Images of nature and society in Amazonian Ethnology".Annual Review of Anthropology, 25: 179-200.

* Trabalho originalmente apresentado no seminário temático Horizontes da Etnologia Indígena: Cosmologias e Formas de Sociabilidade na América do Sul, coordenado por Aparecida Vilaça e Márcio Silva, XXI Encontro Anual da Anpocs, Caxambu, MG, 21-25 de outubro de 1997. O ESRC - Economic and Social Research Council of Great Britain financiou a pesquisa doutoral entre os Kaxinauá do Acre, realizada nos anos 1983-85. A Leverhulme Foundation e a Nuffield Foundation financiaram visitas posteriores. A Anpocs forneceu a oportunidade de apresentar os resultados. Agradeço a todos. Deveria agradecer especialmente aos próprios Kaxinauá e aos antropólogos e indigenistas que me ajudaram no Acre. Finalmente, sou grata a Aparecida Vilaça e Márcio Silva, por terem me estimulado a escrever este artigo, e a todos que participaram do seminário por eles organizado. 